\section{Application of the "4R" Nutrient Stewardship Concept to Horticultural Crops: Getting Nutrients in the "Right" Place}

\author{
David R. Bryla ${ }^{1}$
}

ADDITIONAL INDEX WORDs. fertilizer management, plant nutrient uptake, nutrient use efficiency, root development, soil nutrient availability

SUMMARY. Right fertilizer placement is one of the 4Rs of an effective nutrient stewardship system and should be combined with considerations for the right fertilizer source, rate, and timing. Fertilizer placement decisions depend on mobility of applied nutrients in the soil and the depth and distribution of the crop's root system. Various methods are used to apply fertilizers to horticultural crops, including broadcasting, banding, fertigation, foliar application, and microinjection. Generally, the most appropriate method for any crop increases productivity and profitability and improves fertilizer use efficiency but varies depending on the nutrient element, fertilizer source, soil characteristics, cultural practices, stage of crop development, weather conditions, and farming enterprise constraints. Comparisons among application methods are available for many crops and provide useful information for improving fertilizer placement practices, but many practical questions such as how fertilizer source and availability are affected by irrigation interactions or whether there are ways to manage crop roots for more effective nutrient uptake still remain.

$\mathrm{T}$ he $4 \mathrm{R}$ nutrient stewardship concept was introduced by Bruulsema et al. (2009) to define the right source, rate, time, and place to apply fertilizers to produce not only the most economical outcome in any given crop but also to provide desirable social and environmental benefits essential to sustainable agriculture. The concept was structured around agronomic crops, including corn (Zea mays), soybean (Glycine max), and wheat (Triticum aestivum), but the principals are easily adaptable to other cropping systems. In this article, the utility of the concept is illustrated to discuss the importance of "right" fertilizer placement in horticulture.

Proper fertilizer placement is an integral part of effective and appropriate crop nutrient management. It is basically defined as applying the fertilizer to a location in the soil that maximize plant nutrient uptake and minimize soil nutrient losses (because

Horticultural Crops Research Unit, Agricultural Research Service, U.S. Department of Agriculture, Corvallis, OR 97330

This paper was part of the workshop "Examining the $4 \mathrm{R}$ Concept of Nutrient Management: Right Source, Right Rate, Right Time, Right Place" held on 4 Aug. 2010 at the ASHS Conference, Palm Desert, CA, sponsored by the Plant Nutrient Management (PNM) Working Group.

${ }^{1}$ Corresponding author. E-mail: david.bryla@ars.usda. gov.
SoIl NUTRIENT MOVEMENT AND
AVAILABILITY. Soil nutrients move to
plant roots by a combination of mass
flow and diffusion (Barber, 1995). Mas
flow occurs when dissolved nutrients

SoIL NUTRIENT MOVEMENT AND
AVAILABILITY. Soil nutrients move to
plant roots by a combination of mass
flow and diffusion (Barber, 1995). Mass
flow occurs when dissolved nutrients

SoIL NUTRIENT MOVEMENT AND
AVAILABILITY. Soil nutrients move to
plant roots by a combination of mass
flow and diffusion (Barber, 1995). Mass
flow occurs when dissolved nutrients

\section{Factors affecting fertilizer placement}

SoIL NUTRIENT MOVEMENT AND
AVAILABILITY. Soil nutrients move to
plant roots by a combination of mass
flow and diffusion (Barber, 1995). Mass
flow occurs when dissolved nutrients

of leaching, volatilization, and runoff
as well as immobilization associated and environmental consequences. This ticle will address fertilizer placem tors, recognizing that final placement decisions are site and situation specific. cal processes). Considerations include trients, size and distribution of the placed correctly ensure that nutrients are readily available for plant uptake ( are transported to the root surface by convective water movement driven by evapotranspiration and percolation and subsurface flow of water following rain or irrigation. Diffusion, on the other hand, is a result of concentration gradients created when the uptake rate of ions exceed the supply by mass flow. In general, mass flow generally occurs over much longer distances than diffusion. The relative contribution of each process to nutrient movement depends on soil type and conditions, plant species (because of differences in water use and nutrient uptake), and the chemical characteristics of the particular nutrient. In many arable soils, most of the nitrogen $(\mathrm{N})$ in nitrate form $\left(\mathrm{NO}_{3}-\mathrm{N}\right)$, calcium $(\mathrm{Ca})$, magnesium $(\mathrm{Mg})$, sulfur $(\mathrm{S})$, copper $(\mathrm{Cu})$, boron $(\mathrm{B})$, and manganese $(\mathrm{Mn})$ move to the roots by mass flow, whereas ammonium-nitrogen $\left(\mathrm{NH}_{4}-\mathrm{N}\right)$, phosphorus $(\mathrm{P})$, potassium $(\mathrm{K})$, iron $(\mathrm{Fe})$, zinc $(\mathrm{Zn})$, and molybdenum (Mo) move largely by diffusion; however, any nutrient may move primarily by diffusion when deficient, and most can move by mass flow when adequately supplied and soil sorption of the nutrient is limited.

Numerous studies have noted the importance of nutrient movement associated with placement of $\mathrm{P}$ fertilizer. In most soils, $\mathrm{P}$ moves almost entirely by diffusion, especially under cooler conditions, advancing only a few centimeters over several months. Soluble $\mathrm{P}$, whether derived from fertilizer or natural weathering, reacts with clay, $\mathrm{Ca}, \mathrm{Fe}$, and aluminum $(\mathrm{Al})$ compounds in the soil and is converted readily to less available forms by soil $\mathrm{P}$ fixation. In general, fine-textured soils such as clay loams have a greater P-fixing capacity than sandy, coarse-textured soils (Harris et al., 1996). Potassium is also attracted to the surface of clay minerals, where it may be firmly bound or fixed between the clay layers in a form slowly available to plants. The actual amount of $\mathrm{P}$ and $\mathrm{K}$ available depends on the type and

\begin{tabular}{llll}
\hline $\begin{array}{l}\text { Units } \\
\begin{array}{l}\text { To convert U.S. to SI, } \\
\text { multiply by }\end{array}\end{array}$ & U.S. unit & SI unit & $\begin{array}{l}\text { To convert SI to U.S., } \\
\text { multiply by }\end{array}$ \\
\hline 0.4047 & $\mathrm{acre}(\mathrm{s})$ & $\mathrm{ha}$ & 2.4711 \\
0.3048 & $\mathrm{ft}$ & $\mathrm{m}$ & 3.2808 \\
3.7854 & $\mathrm{gal}$ & $\mathrm{L}$ & 0.2642 \\
2.54 & inch(es) & $\mathrm{cm}$ & 0.3937 \\
1.1209 & $\mathrm{lb} / \mathrm{acre}$ & $\mathrm{kg} \cdot \mathrm{ha}^{-1}$ & 0.8922
\end{tabular}
\title{
.
}


amount of clay present. Most clay minerals are aluminosilicates and are divided into groups based on the number of sheets of silicon $(\mathrm{Si})$ and $\mathrm{Al}$ atoms in their unit layers. Clays of the $1: 1$ type such as kaolinite have a greater fixing capacity than the $2: 1$ type clays such as montmorillonite, illite, and vermiculite. Soils formed under high rainfall and warm temperatures contain large amounts of kaolinitic clays as well as $\mathrm{Fe}$ and $\mathrm{Al}$ oxides, which contributes greatly to the fixation of $\mathrm{P}$ added to these soils.

Nitrate ions, in contrast, are very mobile in soil and move readily to plant roots when applied directly as $\mathrm{NO}_{3}$ fertilizer or when it is converted from the $\mathrm{NH}_{4}$ form by nitrification. Most crop plants prefer $\mathrm{NO}_{3}-\mathrm{N}$ for uptake and therefore placement of $\mathrm{N}$ fertilizers is usually considered less important than when applying immobile fertilizer nutrients such as $\mathrm{P}$, particularly in mature plants. However, many calcifuges or "acid-loving" plants such as blueberry (Vaccinium sp.) and rhododendron (Rhododendron sp.) prefer $\mathrm{NH}_{4}-\mathrm{N}$, in which case placement of $\mathrm{N}$ fertilizers may be more critical (Korcak, 1988).

Sulfur in sulfate form $\left(\mathrm{SO}_{4}-\mathrm{S}\right)$ absorbed by plant roots is also mobile in soil similar to $\mathrm{NO}_{3}$ but tends to be sorbed more by clay particles. In soils with sandy topsoil and relatively high amounts of clay in the subsoil, crops may become $S$ deficient during establishment but respond little to $S$ application once the roots penetrate the subsoil (e.g., Brennan and Bolland, 2006). Sulfur fertilizers in this case are often applied next to the seeds or young plants, either before or shortly after planting.

The amount of movement of fertilizers and nutrients is dependent upon availability of water in the soil or soilless substrate. Both mass flow and diffusion decrease at lower soil water contents as root water uptake declines and the pathway for nutrient ions to root surface becomes more tortuous. This often happens in topsoil, especially under warm, dry conditions when transpiration is high (Mackay and Barber, 1985a, 1985b; Seiffert et al., 1995). Without irrigation, placement of fertilizers below the soil surface can increase availability of $\mathrm{N}$ and other nutrients during these dry periods (Eck and Fanning, 1961). Although fertilizer placement is considered to be particularly important under such circumstances, greater benefits have been found with irrigation than without it, which suggests a possible synergism between fertilizer placement and soil moisture (Rahn, 1996).

Numerous other factors affect movement and availability of soil nutrients, including temperature, soil pH and redox potential, soil organic matter content, soil compaction, interactions with other nutrients, root exudates, and biological activity of soil fauna and microorganisms in the soil and rhizosphere. The relative importance of each to nutrient availability is often site specific and may change over the season. At lower springtime soil temperatures, soil chemical reactions and nutrient movement to plant roots are typically much slower than during summer months. To minimize this problem, small amounts of $\mathrm{P}$ and $\mathrm{K}$ fertilizer are often placed close to the seeds at spring planting so that the nutrients are readily available at germination (Stone, 1998). Certain practices such as mulching likewise affect soil temperature (Tarara, 2000) and therefore may also affect nutrient availability and uptake. Since organic mulches such as sawdust often cool the soil, placing fertilizers closer to the roots may be more essential when using these products; the opposite may be true when using plastic mulches, which often warm the soil (Kumar and Dey, 2011).

Soil $\mathrm{pH}$ affects availability of soil nutrients mainly through its influence on nutrient solubility and ionic form. At different $\mathrm{pH}$ levels, some nutrients may be deficient, whereas others might reach concentrations high enough to cause problems with toxicity (Epstein and Bloom, 2005). For example, at high basic $\mathrm{pH}$, most micronutrients, including $\mathrm{Fe}, \mathrm{B}, \mathrm{Cu}, \mathrm{Mn}$, and $\mathrm{Zn}$, suffer from solubility problems, whereas the macronutrients, with the exception of $\mathrm{P}$, become more available. Fertilizers often affect soil $\mathrm{pH}$ and thereby may indirectly affect the solubility of other nutrients. The most obvious is the source of $\mathrm{N}$ fertilizer used. Nitrate fertilizers often increase soil $\mathrm{pH}$ in the rhizosphere through hydroxyl ion $\left(\mathrm{OH}^{-}\right)$exchange during root uptake of $\mathrm{NO}_{3}{ }^{-}$, whereas $\mathrm{NH}_{4}$ fertilizers acidify the soil largely through the process of nitrification as well as through hydrogen ion $\left(\mathrm{H}^{+}\right)$exchange during root $\mathrm{NH}_{4}{ }^{+}$uptake. These processes have important effects on $P$ availability near the roots, as well as that of micronutrients. Under very acidic conditions, $\mathrm{P}$ is precipitated as $\mathrm{Fe}$ or $\mathrm{Al}$ phosphates of low solubility. Maximum availability of $\mathrm{P}$ generally occurs in a $\mathrm{pH}$ range of 6.0 to 7.0 , which is sometimes a benefit of liming acid soils. Heavy applications of organic materials such as manure, plant residues, or green manure crops to soils with high $\mathrm{pH}$ values not only supplies soil nutrients through mineralization, but upon decomposition, provides acidic compounds which increase the availability of mineral forms of $\mathrm{P}$ and micronutrients.

Interaction between individual soil nutrients may also influence placement of fertilizers due to a mix of plant physiology, soil biology, cation competition, etc. Application of $\mathrm{NH}_{4}-\mathrm{N}$ with $\mathrm{P}$, for example, increases $\mathrm{P}$ uptake from a fertilizer as compared with applying $\mathrm{P}$ fertilizer alone. Application of elemental $S$ or reduced sulfur materials such as ammonium thiosulfate may also increase the availability of P on neutral or basic soils, when the $S$ is oxidized by soil bacteria to produce sulfuric acid (Tisdale et al., 1985). As a result of cation competition, high $\mathrm{K}$ fertilization can decrease the availability of $\mathrm{Mg}$ to the plant and may result in $\mathrm{Mg}$ deficiency of crops grown on soils that are already low in Mg [e.g., chrysanthemum (Chrysanthemum sp.) and grape (Vitis sp.) (Branson et al., 1968; Peacock and Christensen, 1996)]. Conversely, crops grown on soils high in $\mathrm{Mg}$ can suffer $\mathrm{K}$ deficiency, especially if the soils are high in $\mathrm{P}$ and low in $\mathrm{K}$. In such cases, $\mathrm{K}$ and $\mathrm{Mg}$ fertilizers are often applied together as potassium magnesium sulfate.

Root SYSTEM DEVELOPMENT. As a plant's root system develops, the actively growing roots move into new soil spaces and intercept plantavailable nutrients. In general, plants with higher amounts of root surface area intercept more soil nutrients. Interception of these nutrients may be enhanced by mycorrhizal fungi, which colonize the roots and transfer soil nutrients to the host plant from a finely branched network of external hyphae (Smith and Read, 2008). Root and hyphal interception is responsible for an appreciable amount of Ca uptake, as well as $\mathrm{Mg}, \mathrm{Zn}$, and $\mathrm{Mn}$ (Barber, 1995). 
For efficient uptake of plant nutrients, fertilizers should generally be placed as close to the plant roots as possible. Research on apple (Malus $\times$ sylvestris var. domestica), grapefruit (Citrus $\times$ paradisi on Citrus aurantium rootstock), and grape (Vitis rupestris $\times$ Vitis riparia) indicates that nutrient uptake is highest in young roots less than 20 -d old, and uptake rates decline sharply as the root ages (Bouma et al., 2001; Volder et al., 2005). Thus, applying fertilizer where new root growth occurs allows plants to take up more nutrients and reduces the risk of fertilizer loss, provided nutrient concentrations remain low enough to avoid salinity problems and prevent damage to the roots. New root production is regulated at least in part by soil temperature (Kasper and Bland, 1992; McMichael and Burke, 1998), although it is also affected by stage of plant development and the availability of soil water and nutrients (Barber et al., 1988; Dong et al., 2001; Hogue and Neilsen, 1986; Jackson and Bloom, 1990; Tagliavini et al., 1991; Tsegaye et al., 1995). In annual and transplanted perennial crops, new roots emerge from the seed, bare root, or root ball and develop in response to favorable soil conditions. Fertilizers are thus often applied in the vicinity of the seed or roots of the young plants [e.g., by banding with the seeds during sowing or by mixing with the soil in the bottom of the planting hole before transplanting (Watson, 1994)]. In established woody perennials, new roots are generally considered to extend a distance in the soil equivalent to the spread of the branch tips, referred to as the tree or shrub dripline or slightly further. Fertilizer recommendations are often based on this assumption. However, excavation of root systems of trees grown in Florida and New Jersey revealed that the lateral spread of the root system extended well beyond the dripline in six species examined (Gilman, 1988). On average, the tree roots spread close to three times the spread of the branches. Research is needed to determine optimum placement of fertilizers in mature trees and shrubs.

Rooting depth may also be an important consideration when applying fertilizers. The vertical distribution of roots increases with plant age and varies considerably in crops, even among cultivars of the same species (Sponchiado et al., 1989; ThorupKristensen and van den Boogaard, 1998). In general, shallow-rooted plants are probably more sensitive to fertilizer placement than those that are deep-rooted as mobile nutrients such as $\mathrm{NO}_{3}-\mathrm{N}$ are more easily leached below the root zone (although care is also needed when applying immobile nutrients such as $\mathrm{P}$ to deep-rooted crops). Therefore, more care is needed when applying fertilizers soon after planting or to crops with shallow root systems. To illustrate, northern highbush blueberry (Vaccinium corymbosum) plants were fertilized on either one side or both sides of the planting bed using equal amounts of $\mathrm{N}$ fertilizer (Table 1). Roots were concentrated in the top $20-30 \mathrm{~cm}$ of soil profile, which is common in blueberry (Bryla and Strik, 2007). When fertilizer was applied to only one side, plants had lower leaf $\mathrm{N}$ concentrations (on the east side of the plant) than those fertilized on both sides, indicating the plants fertilized on both sides used more of the $\mathrm{N}$ fertilizer and less fertilizer probably leached below the roots. Gough (1984) observed in potted plants with split root systems that blueberry had limited ability to transfer nutrients from roots on one side of the pot to shoots on the other side. However, this does not appear to be the case in the field as leaf $\mathrm{N}$ levels were similar on both sides of the plant even when fertilizer was applied to only side (Table 1 ).

Plant roots often grow preferentially in regions of soil where water and fertilizer are applied. Root growth is especially stimulated by localized application of $\mathrm{N}$ and $\mathrm{P}$ (Drew 1975; Rose et al., 2009), and therefore both $\mathrm{N}$ and $\mathrm{P}$ fertilizers are often placed together at planting (Jing et al., 2010). Root growth is also stimulated by irrigation, and in dry soils will concentrate where soil water availability is highest. Figure lA shows the typical effect of drip irrigation on root distribution in peach (Prunus persica var. persica) trees grown in central California. In this case, nearly all the fine roots were located just above and below the buried drip emitters, limiting tree access to both soil water and nutrients. In comparison, roots from trees irrigated by microsprays were evenly distributed throughout the soil profile (Fig. 1B). Drip irrigation likewise produced shallow, concentrated root systems in apple trees on dwarfing rootstock, resulting in nutrient deficiencies such as $\mathrm{K}$, not normally observed in traditional sprinkler-irrigated orchards with widely spaced trees (Neilsen et al., 1997). Clearly, broadcasting fertilizers over the soil surface provides limited benefit to plants irrigated by drip.

Table 1. Leaf nitrogen $(\mathrm{N})$ concentration of mature blueberry plants grown with $\mathrm{N}$ fertilizer applied on both sides, one side (east or west), or neither side (none) of the planting bed. ${ }^{z}$

\begin{tabular}{lccc}
\hline & & Leaf N (\%) & \\
\cline { 2 - 4 } N fertilizer application & East side of plant & West side of plant & Avg of both sides of plant \\
\hline Both sides & $1.81 \mathrm{a}^{\mathrm{y}}$ & 1.69 & $1.75 \mathrm{a}$ \\
East side only & $1.69 \mathrm{ab}$ & 1.68 & $1.68 \mathrm{ab}$ \\
West side only & $1.63 \mathrm{~b}$ & 1.65 & $1.64 \mathrm{bc}$ \\
None & $1.55 \mathrm{~b}$ & 1.61 & $1.58 \mathrm{c}$ \\
Significance & $*$ & $\mathrm{NS}$ & $*$
\end{tabular}

${ }^{2}$ Leaf samples were collected on 6 Aug. 2009 from 6-year-old 'Elliott' blueberry plants grown in Corvallis, OR. Plants were spaced $2.5 \times 10 \mathrm{ft}(0.76 \times 3.05 \mathrm{~m})$ apart on raised beds $[\approx 1.2 \mathrm{ft}(0.37 \mathrm{~m})$ high and $3 \mathrm{ft}(0.91 \mathrm{~m})$ wide $]$. The beds were mulched every other year with 2 inches $(5.1 \mathrm{~cm})$ of douglas fir $($ Pseudotsuga menziesii) sawdust. In fertilized treatments, ammonium sulfate was banded [both sides or one side only; $\approx 8$ inches $(20.3 \mathrm{~cm})$ from the bed center] in three equal applications (once in April, May, and June) at a rate of $150 \mathrm{~kg} \cdot \mathrm{ha}^{-1}(133.8 \mathrm{lb} /$ acre $) \mathrm{N}$ during the year of the study; lower rates of $\mathrm{N}$ were applied to both sides of each treatment in previous years, following the recommendations of Hart et al. (2006). The sawdust was removed from the banded area before each fertilizer application and replaced after the fertilizer was applied; the fertilizer was washed in by rain and always applied a day before a forecasted rain event. The leaf samples were oven-dried immediately after collection and analyzed for percent $\mathrm{N}$ using a combustion analyzer.

'Means were separated within columns using Fisher's protected least significant difference test at the 0.05 level.

Ns, *Nonsignificant or significant at $P \leq 0.05$, respectively. 
Therefore, many growers using drip apply fertilizers by fertigation (i.e., inject soluble fertilizers through the irrigation water). With fertigation, the amount, concentration, and timing of fertilizers applied are easily controlled (Kafkafi and Tarchitzky, 2011). Fertilizer placement is also easily controlled through emitter spacing and the number and location of drip laterals in each row.

\section{Fertilizer placement methods}

Methods commonly used to apply fertilizers to horticultural crops are summarized in Table 2. They include broadcasting, banding, fertigation,
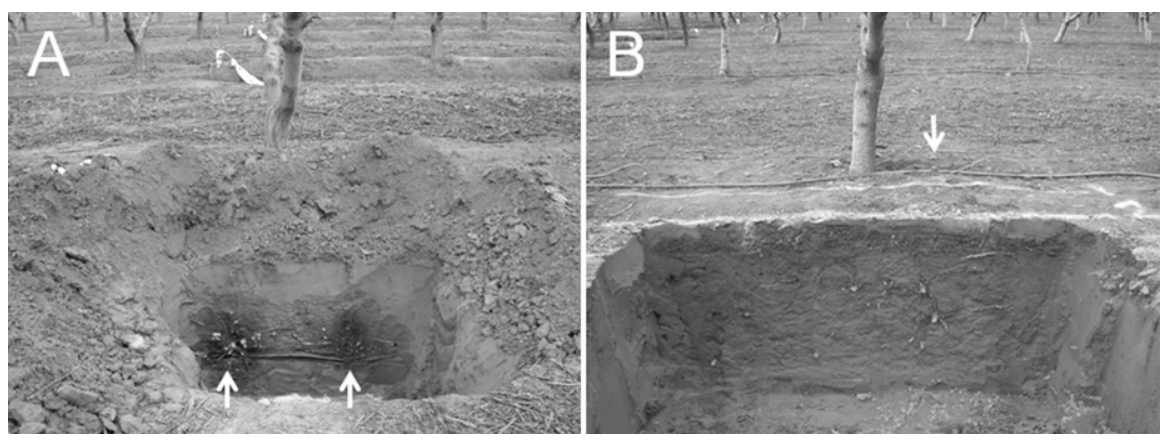

Fig. 1. Fine root distribution of peach trees irrigated by (A) subsurface drip or (B) microsprays. Subsurface drip lines had $2 \mathrm{~L} \cdot \mathrm{h}^{-1}(0.53 \mathrm{gal} / \mathrm{h})$ in-line emitters spaced every $0.45 \mathrm{~m}$ and were buried $1.5 \mathrm{ft}(0.45 \mathrm{~m})$ deep and $4 \mathrm{ft}(1.2 \mathrm{~m})$ from each side of the tree row. Microsprays $\approx 6 \mathrm{ft}(1.8 \mathrm{~m})$ diameter, $270^{\circ}$ wetting pattern and were located in the center of the row near the base of each tree. Arrows indicate the location of the irrigation emitters. See Bryla et al. (2005) for more details on the planting (photographs were taken by J. Gartung).
Broadcast. Broadcast fertilizers are spread evenly over a field or landscape using hand-operated or wheeled spreaders or dropped from an aircraft. The fertilizer may be either left on the soil surface as a "topdress" or "incorporated" into the soil by disking or plowing. Nutrients that are often broadcast include $\mathrm{N}, \mathrm{P}, \mathrm{K}, \mathrm{S}, \mathrm{Ca}, \mathrm{Mg}$, and $\mathrm{B}$. Copper, $\mathrm{Mn}$, and $\mathrm{Zn}$ are also sometimes broadcast, although banding or foliar application is typically more efficient.

Topdress broadcast application is usually applied after planting and washed in by rain or sprinkler irrigation. It is an easy, inexpensive way to apply fertilizers to large areas without mechanically damaging the plants. Topdressing is often used in horticulture for lawns and large areas of landscaping but may be practiced in crops grown in dense stands such as cranberry (Vaccinium macrocarpon) and lowbush blueberry (Vaccinium angustifolium), in plants with widespread root systems such as citrus (Citrus sp.) and nut trees, in fertile soils, especially when high rates and readily soluble forms of $\mathrm{N}$ fertilizers are applied, and when applying $\mathrm{K}$ fertilizers to sandy soils. The method is inefficient, however, for widely spaced crops, for application of immobile nutrients such as $\mathrm{P}, \mathrm{Fe}$, and $\mathrm{Zn}$, and for applying $\mathrm{N}$ fertilizer in sandy soils where $\mathrm{NO}_{3}-\mathrm{N}$ is readily leached. It also stimulates weed growth and may enhance $\mathrm{N}$ losses associated with denitrification and volatilization.

Table 2. Common fertilizer placement methods used for horticultural crops.

\begin{tabular}{|c|c|c|}
\hline Method & Description & Common crops \\
\hline \multicolumn{3}{|l|}{ Broadcast } \\
\hline Topdress & $\begin{array}{l}\text { Fertilizer is dropped or spread evenly on the soil } \\
\text { surface without working it into the soil }\end{array}$ & $\begin{array}{l}\text { Turf, small grains, vegetables, fruit and nut } \\
\text { trees, cranberry, lowbush blueberry }\end{array}$ \\
\hline Incorporated & $\begin{array}{l}\text { Fertilizer is spread on the soil surface and plowed or } \\
\text { disked under during soil preparation }\end{array}$ & All \\
\hline \multicolumn{3}{|l|}{ Banding } \\
\hline Pop-up or starter & $\begin{array}{l}\text { Fertilizer is placed with or near the seed or transplant } \\
\text { at planting }\end{array}$ & Vegetables, trees, and shrubs \\
\hline Sidedress & $\begin{array}{l}\text { Fertilizer is spread alongside a plant or row of plants } \\
\text { after planting }\end{array}$ & Vegetables, trees, and shrubs \\
\hline Fertigation & $\begin{array}{l}\text { Fertilizer is applied through the irrigation water. Drip, } \\
\text { furrow, or sprinkler irrigation can be used }\end{array}$ & All \\
\hline Foliar & Liquid fertilizer is sprayed directly on the leaves & Trees and shrubs \\
\hline Microinjection & $\begin{array}{l}\text { Direct injection of necessary nutrients into the trunk of } \\
\text { the tree or shrub }\end{array}$ & Landscape trees and shrubs \\
\hline
\end{tabular}


Incorporated broadcast application is typically done before planting and may be used in any crop to improve the general soil fertility. Because the fertilizer is mixed in the soil, less mobile nutrients such as $\mathrm{P}$ and $\mathrm{K}$ are more available to plant roots. Fertilizer injury is minimized by this method, but on deep, sandy soils, $\mathrm{N}$ and $\mathrm{S}$ may be lost by leaching, especially when followed by heavy rains. More fertilizer is required to obtain equivalent yields in row crops than is needed with banding.

Banding. Banded fertilizers are placed in a concentrated area along the plant row. The fertilizer may be placed with the seed at planting as "pop-up" fertilizer or placed near the seed or transplant as "starter" fertilizer. A band of fertilizer applied on or below the soil surface after planting is commonly referred to as a "sidedress" application. Fertilizer banding is often practiced in crops planted in wide rows. The most common banded fertilizers are $\mathrm{N}$ and $\mathrm{P}$, although $S$ and micronutrients such as $\mathrm{Zn}$ can be applied efficiently as starter fertilizers.

Pop-up and starter fertilizer may increase early growth with considerably less fertilizer than broadcasting because the nutrients are located directly near the plants. These fertilizers generally contain low amounts of soluble $\mathrm{N}$ and high amounts of $\mathrm{P}$. The N improves P uptake, particularly during the spring when soil temperatures are cooler, and the $\mathrm{P}$ promotes root growth and plant vigor (Burns et al., 2010). A good response in establishment and early growth has been shown in carrot (Daucus carota var. sativus), cabbage (Brassica oleracea var. capitata), onion (Allium cepa), lettuce (Lactuca sativa), and green bean (Phaseolus vulgaris) to small quantities of $\mathrm{P}$ and $\mathrm{N}$ fertilizers injected at sowing beneath the seeds (Stone, 1998, 2000; Stone et al., 1999). The nutrients in this case were ideally placed to produce a significant growth response and are much more effective than a similar quantity of broadcast nutrient. Positioning the fertilizer close to seed or plant also decreases the amount available to weeds and may reduce problems with root disease. Deep banding of $\mathrm{N}, \mathrm{P}$, and $\mathrm{S}$ fertilizer below each seed row increased growth and yield compared with banding between alternate seed rows in cereals exposed to root disease (Cook et al., 2000).

A major concern with the use of pop-up and starter fertilizers is the potential for salt injury or ammonia toxicity if the fertilizer rate is too high. Severe stand reductions and yield losses may occur with the use of excessive rates of seed- or transplant-applied fertilizers, even in larger plants. A N-P-K fertilizer mixed in the soil under 2-year-old rabbiteye blueberry [Vaccinium virgatum (synonym Vaccinium ashei)] before planting caused up to $54 \%$ of the plants to die compared with $0 \%$ to $6 \%$ when no fertilizer was applied (Austin and Bondari, 1989). Many $\mathrm{N}$ and $\mathrm{K}$ fertilizers have high salt indexes. Consequently, when placed too close to seeds or transplants, they can decrease seed germination and plant survival. This fertilizer injury is most severe on sandy soils, under dry conditions, and with high rates of fertilization. Pop-up and starter fertilizers also concentrate root growth where the fertilizer is applied, potentially reducing the plant's ability to acquire water and nutrients during later stages of development. Starter fertilizer solution concentrated new root development in broccoli (B. oleracea var. italica), which later increased the crop requirement for irrigation (Rahn, 1996).

Sidedress fertilizer is used to supplement fertilizers applied preplant or during planting. Most vegetables require a sidedress application of $\mathrm{N}$ fertilizer after thinning to meet $\mathrm{N}$ demands for continued crop growth. Sidedress fertilizer may be placed in a band on the soil surface and incorporated by watering or tillage or deep banded below the soil surface with a knife or shank. Subsurface placement is normally used to control $\mathrm{N}$ losses. Anhydrous ammonia, for example, although rarely used in horticultural crops, is usually placed and sealed below the surface to eliminate direct volatilization losses of the gaseous ammonia. Incorporating urea fertilizers is also important, especially in no-till and turfgrass situations where volatilization of ammonia is aggravated by large amounts of organic material on the soil surface. Tilled and shanked fertilizers should be applied far enough from the plant to avoid root injury.
Subsurface sidedressing places fertilizer directly near the roots and reduces soil $\mathrm{P}$ and $\mathrm{K}$ fixation because compared with broadcasting the total amount of contact between the soil and the fertilizer is minimized. These benefits improve $\mathrm{P}$ and $\mathrm{K}$ use efficiency and therefore reduce the amount of fertilizer needed. A sidedress of $\mathrm{K}$ fertilizer restricted to the herbicide strip substantially reduced the amount of fertilizer needed to maintain optimal nutrient levels in young apple trees compared with broadcasting the fertilizer (Ystaas and Frøynes, 1993). Sidedressing, however, may increase the loss of $\mathrm{N}$ and $\mathrm{S}$ fertilizers if the nutrients are leached by rain or irrigation before being absorbed by the crop. The method also slows fertilizer application compared with broadcasting and requires more expensive equipment or equipment modifications.

Fertigation. Fertigation is the practice of applying soluble fertilizer through the irrigation water. The practice has increased dramatically in recent years, primarily due to higher use of drip and other low-flow irrigation systems such as microsprinklers, where fertilizers are injected easily. In the United States, drip and microsprinkler irrigation increased from 3.0 million acres in 2003 to 3.8 million acres in 2008 (U.S. Department of Agriculture, 2009). These systems often reduce irrigation water use and increase uniformity of water and fertilizer applications compared with the flood, furrow, and sprinkler systems they replace. Several advantages of fertigation include reduced delivery costs (no need for tractors or spreaders), greater control of where and when the fertilizers are placed, the ability to target application of specific nutrients during particular stages of crop development, and the potential to reduce fertilizer losses by supplying only small amounts of fertilizer to the plants as needed. Disadvantages include costs associated with the need for higher fertilizer quality (i.e., purity and solubility) and the capital costs of the equipment required to inject the fertilizer through the irrigation system.

A large range of fertilizers, both solid and liquid, are suitable for fertigation, but precautions are necessary when mixing fertilizers to prevent the nutrient elements from precipitating and clogging the irrigation emitters. 
For example, fertilizer solutions containing Ca should not be mixed with those containing phosphates or sulfates, unless the solution $\mathrm{pH}$ is sufficiently acidic (Kafkafi and Tarchitzky, 2011). Many fertilizers are corrosive and may harm metallic components of the irrigation system such as steel pipes, valves, filters, and injection units; plastic or stainless steel components are therefore preferred.

Fertilizer injection systems range from simple, inexpensive devices such as venturi-type injectors, which uses vacuum pressure created by flowing water through a constricted section of pipe to transfer fertilizer solution from a fertilizer tank to the irrigation line, to more expensive equipment, such as positive-pressure injection pumps, which operate using hydraulic energy or electricity to inject the nutrient solution. Complex systems such as those used for "open hydroponics," where the entire nutrient needs of the crop are supplied by the fertigation system, rely on a series of control units that allow irrigation pumps to be turned on and off at preset times and use electrical conductivity and $\mathrm{pH}$ sensors to determine exactly when and how much of each fertilizer is injected on a daily basis (Falivene, 2005).

Fertigation is typically considered a very efficient way to apply fertilizers (Kafkafi and Tarchitzky, 2011). When used in conjunction with drip, plant nutrients can be applied directly to the root zone. Because most roots in drip irrigated crops are located near the drip emitters, diffusion-limited nutrients such as $\mathrm{NH}_{4}-\mathrm{N}$ and $\mathrm{P}$ can be placed in the soil region containing the highest root density, reducing ion diffusion distance as well as the potential for soil. Fertigation may also facilitate efficient use of mobile nutrients, including $\mathrm{NO}_{3}$ - and urea-N (Ehaliotis et al., 2010; Quiñones et al., 2003), although excessive water application will quickly reduce efficiency if the fertilizers are pushed below the active root zone (Hanson et al., 2006). Other factors affecting fertigation efficiency include root growth and stage of crop development. In many perennial crops, young plantings irrigated by drip or those recently converted to drip usually have very few roots located near the drip emitters during the first few months after planting or conversion. Under these circumstances, application of granular fertilizers may be more efficient until the root system develops. Weekly $\mathrm{N}$ fertigation, for example, was less efficient than a triplesplit application of granular fertilizer during the first year after planting in blueberry (Fig. 2). By the end of the first season, the young plants required only half as much $\mathrm{N}$ from granular fertilizer as from fertigation to achieve the same amount of growth and leaf $\mathrm{N}$ levels. However, the potential for crop growth was greater with fertigation when more $\mathrm{N}$ was applied. Improved growth was particularly apparent by the end of the second season where $150 \mathrm{~kg} \cdot \mathrm{ha}^{-1} \mathrm{~N}$ applied by fertigation produced nearly twice the canopy cover of any amount of granular fertilizer (Fig. 2). Greater growth in this case was not due to higher $\mathrm{N}$ use efficiency with fertigation but to less salt stress associated with slowly feeding the fertilizer through the drip system (Bryla and Machado, 2011).

Foliar. Soluble fertilizers can be applied as a foliar spray using a hand sprayer, a spray rig, or an aircraft. Plants respond almost immediately to foliar sprays, making them useful for quickly correcting nutrient deficiencies. Foliar sprays may also increase fertilizer use efficiency compared with soil-applied nutrients (Rosecrance et al., 1998), although when macronutrients such as $\mathrm{N}$ are applied, repeated applications are often needed to meet the total annual requirements of the crop (Johnson et al., 2001; Reickenberg and Pritts, 1996). Nitrate leaching was reduced, for example, when apple trees were treated with repeated urea foliar applications compared with the same amount and timing of soil applied urea (Dong et al., 2005). However, as leaves have a limited ability to absorb nutrients, a significant portion of the foliar fertilizer may drip off the leaves and may be absorbed ultimately by the roots (Reickenberg and Pritts, 1996; Strik et al., 2004).

Foliar sprays are most widely used to apply micronutrients (Mortdevt, 2011). A sticker-spreader agent helps the spray adhere to the foliage and is

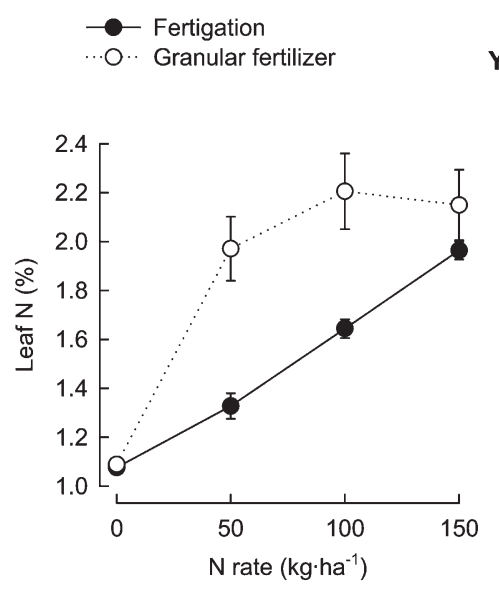

Year 1
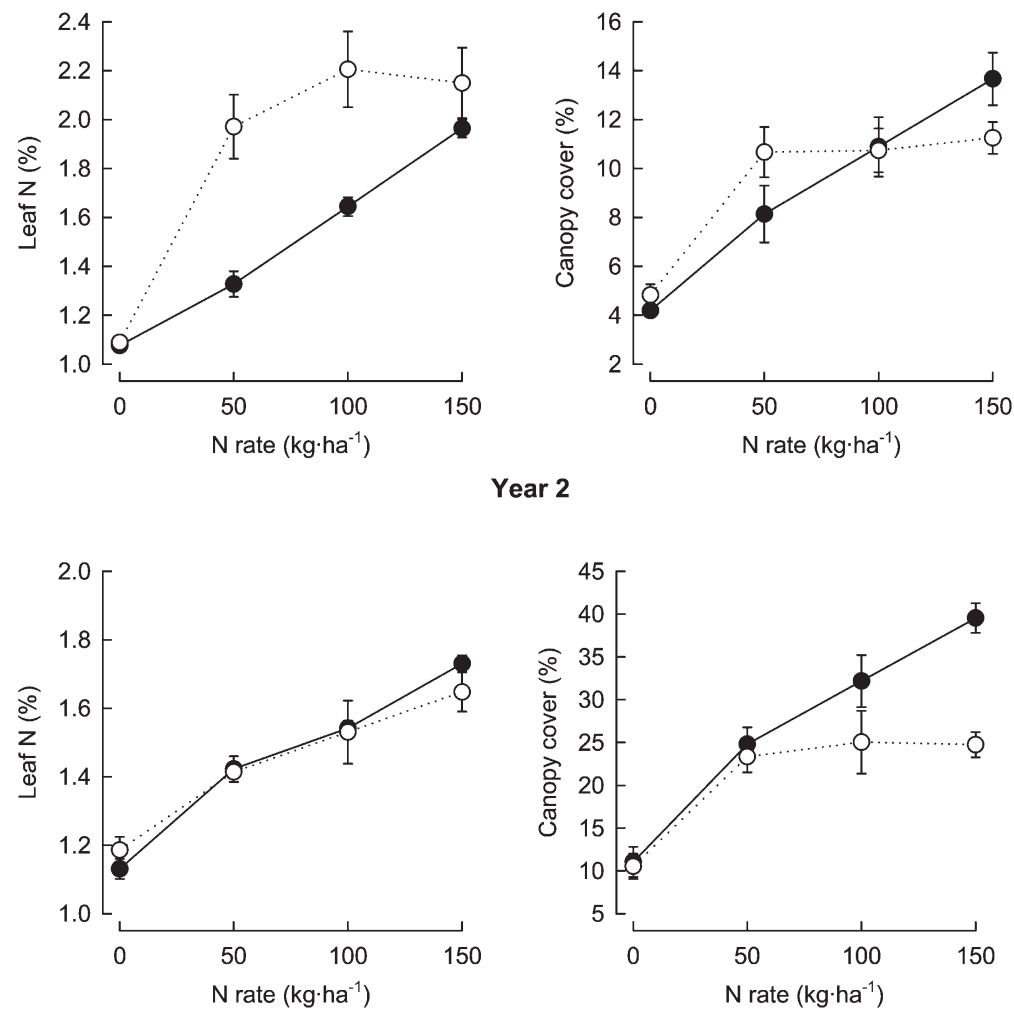

Year 2

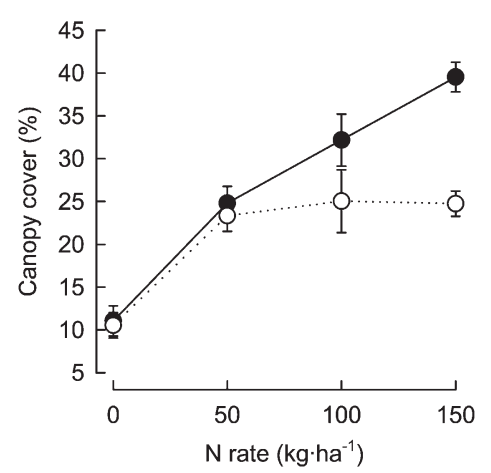

Fig. 2. The effect of four rates of nitrogen $(\mathrm{N})$ fertigation and granular fertilizer on leaf $\mathrm{N}$ concentration and percent canopy cover in highbush blueberry during first 2 years after planting (from Bryla and Machado, 2011); $1 \mathrm{~kg} \cdot \mathrm{ha}^{-1}=0.8922 \mathrm{lb} / \mathrm{acre}$. 
often recommended when applying micronutrient solutions. Foliar sprays are commonly used to correct micronutrient deficiencies in numerous horticultural crops, including many fruit and vegetable, floriculture, and landscape plants.

Microinjection. Microinjection of fertilizer is used by the landscape industry to remedy or invigorate trees demonstrating stress or decline symptoms, particularly when soil application of fertilizer is impractical (e.g., urban environments). The fertilizer is either injected as solution or solidified into gelatin capsules and imbedded into holes drilled in the trunk. The tree then takes up the material through its xylem, whereby the fertilizer is distributed throughout the tree. This technique is best performed in the spring or fall when sap flow within the tree is highest. It works in many different tree species, although some such as american elm (Ulmus americana) contain ring-porous xylem (whereby most of the water transport is confined to the outermost growth layer) and therefore are unable to take up large quantities of nutrients this way (Evert, 2006). Several concerns with microinjection include trunk disfigurement and decay associated with boring the holes and imbedding or injecting the fertilizer and uneven distribution of the fertilizer within the tree crown. It is generally regarded as a short-term solution for nutrient deficiencies but is often coupled with injection of pesticides and fungicides. Soil and foliar fertilizers are often needed for a permanent cure.

\section{Summary and suggestions for future improvements}

Application of fertilizers in the "right" place involves matching the location of the applied nutrients to a position in the soil that is readily assessable to the crop roots. Potential benefits include enhanced seed germination and emergence, improved plant establishment, higher yields and better crop quality, reduced weed competition, and increased profitability. Proper placement can also improve fertilizer use efficiency, helping to reduce nutrient losses associated with nutrient volatilization, runoff, leaching, and soil erosion. Numerous methods have been developed and used to apply fertilizers, but the best choice often varies among nutrients and fertilizers and differs depending on the crop and its associated root development, soil type and the overall soil fertility, the accompanying cultural practices implemented, the stage of crop development, and regional weather conditions. Overall, the "right" placement of fertilizers is an important component of proper " $4 \mathrm{R}$ " nutrient management and must be considered in combination with selection of the "right" fertilizer source (Gaskell and Hartz, 2011), the "right" fertilizer rate (Santos, 2011), and the "right" time to apply the fertilizer (Mattson and van Iersel, 2011). The concept is applicable to most any crop grown in nearly any type of horticultural system.

Considerable research has been done over the years to increase our understanding of nutrient movement in soils and its relationship to root development and plant nutrient uptake. However, while we now have much general knowledge, there is still little operative know-how for many crops of where exactly fertilizer placement is most effective. For example, we still have a limited understanding of the interactive effects among irrigation, fertilizer placement, and root growth. What is the effect of liquid vs. granular fertilizer in relation to soil water availability? Should fertilizer placement differ during rainy months than during drier times of the year when irrigation is needed? Is the optimum number and placement of drip emitters the same for irrigation as it is for fertigation? What is the rooting pattern of different plant species, and how is rooting affected by fertilizer supply and irrigation regime?

Studies in deciduous fruit trees indicate that wetting only $20 \%$ of the potential root system is sufficient to maximize yield (Boland et al., 2000a, 2000 b). Does this hold true for nutrient uptake? If so, this emphasizes the importance of having roots in the right place; i.e., the spatial element of root development may be more important than root quantity. How do we improve crop rooting to increase efficiency of fertilizer application? Rooting varies considerably among genotypes, and certain traits favorable for nutrient capture could be selected during breeding. Large differences in rooting depth occur among vegetables; e.g., lettuce, leek (Allium ampeloprasum var. porrum), and onion are shallow-rooted; carrot is intermediate; and Brassicaceae species are often deep-rooted. This gives rise to different amounts of mineral $\mathrm{N}$ in the soil at harvest.

Research in Denmark focused on finding catch crops that make efficient use of such residues (ThorupKristensen, 2001). This approach, which optimizes the capture of applied $\mathrm{N}$ and other nutrients, could easily be used elsewhere and perhaps for other cropping systems. Certain management practices such as soil tillage, planting distribution, and crop rotation could also be manipulated toward improving placement of fertilizers. Through breeding and successful nutrient management of horticultural crops, we can ultimately ensure that selected fertilizers are positioned and used as efficiently as possible and that plant nutrients are available when needed for optimum production.

\section{Literature cited}

Austin, M.E. and K. Bondari. 1989. Studies on the response of 'Tifblue' and 'Woodard' rabbiteye blueberries to fertilizers. I. Effects of fertilizer placement on plant survival, yield, and fruit size. Nutr. Cycl. Agroecosyst. 20:167-172.

Barber, S.A. 1995. Soil nutrient bioavailability. 2nd ed. Wiley, New York.

Barber, S.A., A.D. Mackay, R.O. Kuchenbuch, and P.B. Barraclough. 1988. Effects of soil temperature and water on maize root growth. Plant Soil 111:267-269.

Boland, A.M., P.H. Jerie, P.D. Mitchell, I. Goodwin, and D.J. Connor. 2000a. Long-term effects of restricted root volume and regulated deficit irrigation on peach. I. Growth and mineral nutrition. J. Amer. Soc. Hort. Sci. 125:135-142.

Boland, A.M., P.H. Jerie, P.D. Mitchell, I. Goodwin, and D.J. Connor. 2000b. Long-term effects of restricted root volume and regulated deficit irrigation on peach. II. Productivity and water use. J. Amer. Soc. Hort. Sci. 125:143-148.

Bouma, T.J., R.D. Yanai, A.D. Elkin, U. Hartmond, D.E. Flores-Alva, and D.M. Eissenstat. 2001. Estimating agedependent costs and benefits of roots with contrasting life span: Comparing apples and oranges. New Phytol. 150:685-695.

Branson, R.L., R.H. Sciaroni, and J.M. Rible. 1968. Magnesium deficiency in cutflower chrysanthemums. Calif. Agr. 22(8): 13-14. 
Brennan, R.F. and M.D.A. Bolland. 2006. Soil and tissue tests to predict the sulfur requirements of canola in southwestern Australia. Aust. J. Exp. Agr. 46: 1061-1068.

Bruulsema, T., J. Lemunyon, and B. Herz. 2009. Know your fertilizer rights. Crop Soils 42:13-18.

Bryla, D.R., E. Dickson, R. Shenk, R.S. Johnson, C.H. Crisosto, and T.J. Trout. 2005. Influence of irrigation method and scheduling on patterns of soil and tree water status and its relationship to yield and fruit quality in peach. HortScience 40:2118-2124.

Bryla, D.R. and R.M.A. Machado. 2011. Comparative effects of nitrogen fertigation and granular fertilizer application on growth and availability of soil nitrogen during establishment of highbush blueberry. Frontiers Crop Sci. Hort. 2:1-8.

Bryla, D.R. and B.C. Strik. 2007. Effects of cultivar and plant spacing on the seasonal water requirements of highbush blueberry. J. Amer. Soc. Hort. Sci. 132: 270-277.

Burns, I.G., J.P. Hammond, and P.J. White. 2010. Precision placement of fertiliser for optimising the early nutrition of vegetable crops: A review of the implications for the yield and quality of crops, and their nutrient use efficiency. Acta Hort. 852:177-187.

Cook, R.J., B.H. Ownley, H. Zhang, and D. Vakoch. 2000. Influence of paired-row spacing and fertilizer placement on yield and root diseases of direct-seeded wheat. Crop Sci. 40:1079-1087.

Dong, S., D. Neilsen, G.H. Neilsen, and L.H. Fuchigami. 2005. Foliar N application reduces soil $\mathrm{NO}_{3}^{-}-\mathrm{N}$ leaching loss in apple orchards. Plant Soil 268:357-366.

Dong, S., C.F. Scagel, L. Cheng, L.H. Fuchigami, and P.T. Rygiewicz. 2001. Soil temperature and plant growth stage influence nitrogen uptake and amino acid concentration of apple during early spring growth. Tree Physiol. 21:541-547.

Drew, M.C. 1975. Comparison of the effects of a localized supply of phosphate, nitrate, ammonium and potassium on the growth of the seminal root system, and the shoot, in barley. New Phytol. 75:479490.

Eck, H.V. and C. Fanning. 1961. Placement of fertilizer in relation to soil moisture supply. Agron. J. 53:335-338.

Ehaliotis, C., I. Massas, and G. Pavlou. 2010. Efficient urea-N and $\mathrm{KNO}_{3}-\mathrm{N}$ uptake by vegetable plants using fertigation. Agron. Sustainable Dev. 30:763768 .
Epstein, E. and A.J. Bloom. 2005. Mineral nutrients of plants: Principles and perspectives. Sinauer Assoc., Sunderland, MA.

Evert, R.F. 2006. Esau's plant anatomy. Meristems, cells, and tissues of the plant body: Their structure, function, and development. 3rd ed. Wiley, Hoboken, NJ.

Falivene, S. 2005. Adopting Open Hydroponics: Factors to Consider. Natl. Program Sustainable Irr. Fact Sheet. 7 Aug. 2011. <http://lwa.gov.au/files/ products/national-program-sustainableirrigation/ef050988/ef050988.pdf>.

Gaskell, M. and T. Hartz. 2011. Application of the " $4 \mathrm{R}$ " nutrient stewardship concept to horticultural crops: Selecting the "right" nutrient source. HortTechnology 21:663-666.

Gilman, E.F. 1988. Predicting root spread from trunk diameter and branch spread. J. Arboriculture 14:85-89.

Gough, R.E. 1984. Split-root fertilizer application to highbush blueberry. HortScience 19:415-416.

Hanson, B., N. O'Connell, J. Hopmans, J. Simunek, and R. Beede. 2006. Fertigation with microirrigation. Univ. California, Agr. Natural Resources Comm. Serv. Publ. 21620 .

Harris, W.G., R.D. Rhue, G. Kidder, R.B. Brown, and R. Little. 1996. Phosphorus retention as related to morphology of sandy coastal plain soil materials. Soil Sci. Soc. Amer. J. 60:1513-1521.

Hart, J., B. Strik, L. White, and W. Yang. 2006. Nutrient management for blueberries in Oregon. Oregon State Univ. Ext. Serv. Publ. EM8918.

Hogue, E.J. and G.H. Neilsen. 1986. Effect of root temperature and varying cation ratios on growth and leaf cation concentration of apple seedlings grown in nutrient solution. Can. J. Plant Sci. 66: 637-645.

Jackson, L.E. and A.J. Bloom. 1990. Root distribution in relation to soil nitrogen availability in field grown tomatoes. Plant Soil 128:115-126.

Jing, J., Y. Rui, Z. Rengel, and J. Shen. 2010. Localized of phosphorus and ammonium improves growth of maize seedlings by stimulating root proliferation and rhizosphere acidification. Field Crops Res. 119:355-364.

Johnson, R.S., R.C. Rosecrance, S.A. Weinbaum, H. Andris, and J. Wang. 2001. Can we approach complete dependence on foliar-applied urea nitrogen in an early-maturing peach? J. Amer. Soc. Hort. Sci. 126:364-370.
Kafkafi, U. and J. Tarchitzky. 2011. Fertigation: A tool for efficient fertilizer and water management. Intl. Fert. Ind. Assn., Paris, France.

Kasper, T.C. and W.L. Bland. 1992. Soil temperature and root growth. Soil Sci. 154:290-299.

Korcak, R.F. 1988. Nutrition of blueberry and other calcifuges. Hort. Rev. 10:183227.

Kumar, S. and P. Dey. 2011. Effect of different mulches and irrigation methods on root growth, nutrient uptake, water use efficiency and yield of strawberry. Sci. Hort. 127:318-324.

Mackay, A.D. and S.A. Barber. 1985a. Soil moisture effects on root growth and phosphorus uptake by corn. Agron. J. 77:519-523

Mackay, A.D. and S.A. Barber. 1985b. Soil moisture effects on potassium uptake by corn. Agron. J. 77:524-527.

Mattson, N.S. and M.W. van Iersel. 2011. Application of the " $4 \mathrm{R}$ " nutrient stewardship concept to horticultural crops: Applying nutrients at the "right time". HortTechnology 21:667-673

McMichael, B.L. and J.J. Burke. 1998. Soil temperature and root growth. HortScience 33:947-951

Mortdevt, J. 2011. Micronutrients. In: Efficient fertilizer use manual. 7 Aug. 2011. <http://www.back-to-basics.net/efu/ pdfs/Micronutrients.pdf $>$.

Neilsen, G.H., P. Parchomchuk, R. Berard, and D. Neilsen. 1997. Irrigation frequency and quantity affect root and top growth of fertigated 'McIntosh' apple on M.9, M.26 and M.7 rootstock. Can. J. Plant Sci. 77:133-139.

Peacock, B. and P. Christensen. 1996. Magnesium deficiency becoming more common. Univ. California Coop. Ext. Publ. NG5-96.

Quiñones, A., J. Bañuls, E. Primo-Millo, and F. Legaz. 2003. Effects of ${ }^{15} \mathrm{~N}$ application frequency on nitrogen uptake efficiency in Citrus trees. J. Plant Physiol. 160:1429-1434.

Rahn, C.R. 1996. The effect of water supply on the response of onions and calabrese to starter solutions. Acta Hort. 428:141-149.

Reickenberg, R.L. and M.P. Pritts. 1996. Dynamics of nutrient uptake from foliar fertilizers in red raspberry (Rubus idaeus L.). J. Amer. Soc. Hort. Sci. 121:158163.

Rose, T.J., Z. Rengel, Q. Ma, and J.W. Bowden. 2009. Crop species differ in root 
plasticity in response to localised P supply. J. Plant Nutr. Soil Sci. 172:360-368.

Rosecrance, R.C., R.S. Johnson, and S.A. Weinbaum. 1998. The effect of timing of post-harvest foliar urea sprays on nitrogen absorption and partitioning in peach and nectarine trees. J. Hort. Sci. Biotechnol. 73:856-861.

Santos, B.M. 2011. Selecting the right nutrient rate: Basis for managing fertilization programs. HortTechnology 21:683-685.

Seiffert, S., J. Kaselowsky, A. Jungk, and N. Claassen. 1995. Observed and calculated potassium uptake by maize as affected by soil water content and bulk density. Agron. J. 87:1070-1077.

Smith, S.E. and D.J. Read. 2008. Mycorrhizal symbiosis. 3rd ed. Academic Press, New York.

Sponchiado, B.N., J.W. White, J.A. Castillo, and P.G. Jones. 1989. Root growth of four common bean cultivars in relation to drought tolerance in environments with contrasting soil types. Exp. Agr. 25: 249-257.

Stone, D.A. 1998. The effect of "starter" fertilizer injection on the growth and yield of drilled vegetable crops in relation to soil nutrient status. J. Hort. Sci. Biotechnol. 73:441-452.
Stone, D.A. 2000. The effects of starter fertilizer on the growth and nitrogen use efficiency of onion and lettuce. Soil Use Mgt. 16:42-48.

Stone, D.A., F.T. Tyler, and S. Runham. 1999. Effect of starter fertilizers on the yield and quality of lettuce grown on peaty soils. Soil Use Mgt. 15:128-132.

Strik, B., T. Righetti, and G. Buller. 2004. Influence of rate, timing, and method of nitrogen fertilizer application on uptake and use of fertilizer nitrogen, growth, and yield of June-bearing strawberry. J. Amer. Soc. Hort. Sci. 129:165-174.

Tagliavini, M., E.J. Hogue, and G.H Neilson. 1991. Influence of phosphorus nutrition and root zone temperature on growth and mineral uptake of peach seedlings. J. Plant Nutr. 14:1267-1276.

Tarara, J.M. 2000. Microclimate modification with plastic mulch. HortScience 35:169-180.

Thorup-Kristensen, K. 2001. Are differences in root growth of nitrogen catch crops important for their ability to reduce soil nitrate-N content, and how can this be measured? Plant Soil 230:185-195.

Thorup-Kristensen, K. and R. van den Boogaard. 1998. Temporal and spatial root development of cauliflower (Brassica oleracea L. var. botrytis L.). Plant Soil 201:37-47.

Tisdale, S.L., W. Nelson, and J. Beaton. 1985. Soil fertility and fertilizers, 4th ed. Macmillan, New York.

Tsegaye, T., C.E. Mullins, and A.J. Diggle. 1995. Modelling pea (Pisum sativum) root growth in drying soil. A comparison between observations and model predictions. New Phytol. 131:179-181.

U.S. Department of Agriculture. 2009. Farm and ranch irrigation survey (2008). U.S. Dept. Agr., Natl. Agr. Stat. Serv., Washington, DC.

Volder, A., D.R. Smart, A.J. Bloom, and D.M. Eissenstat. 2005. Rapid decline in nitrate uptake and respiration with age in fine lateral roots of grape: Implications for root efficiency and competitive effectiveness. New Phytol. 165:493-502.

Watson, G.W. 1994. Root growth response to fertilizers. J. Arboriculture 20: 4-8.

Ystaas, J. and O. Frøynes. 1993. The fertilizer requirement of young apple trees as affected by restricting the fertilizer placement to the herbicide strip. Acta Hort. 347:179-188. 